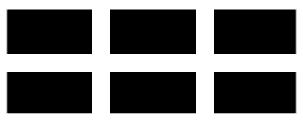

The WiLliam DAVIDSON Institute AT THE UNIVERSITY OF MICHIGAN BUSINESS SCHOOL

The Reorientation of Transition Countries' Exports: Changes in Quantity, Quality and Variety

\author{
By: Yener Kandogan
}

William Davidson Institute Working Paper Number 631

November 2003 


\title{
The Reorientation of Transition Countries' Exports: Changes in Quantity, Quality and Variety
}

\author{
By \\ Yener Kandogan \\ University of Michigan-Flint
}

Running Title: Reorientation of Transition Exports

Correspondence Address:

School of Management

University of Michigan-Flint

303 E. Kearsley

Flint, MI 48502

Phone: (810) 2376675

Fax: (810) 7623282

Email:

yener@umich.edu 


\title{
The Reorientation of Transition Countries' Exports: Changes in Quantity, Quality, and Variety
}

\begin{abstract}
The paper analyzes the factors behind the reorientation of transition countries' exports to their non-traditional partners outside their former block. First, the amount of reorientation is calculated using a gravity model. Then, reasons for the cross-country differences in the rate of closing the gap between the actual and potential exports, such as increases in quantity, quality, and variety, are analyzed using a variety of measures from the literature. The results show that although exports have increased significantly, as of 1999 they are still far below the potential in CIS and to a lesser extent in CEEC. Change in quantity has been the primary reason behind the reorientation of CIS exports. However, it had smaller effect on CEEC reorientation, where increase in product variety has been important. Although some quality improvement is observed in both CEEC and CIS, it had small effect on the extent of reorientation.
\end{abstract}

JEL Classification: F14, F15, P33

Keywords: Eastern Europe, Commonwealth of Independent States, Intra-industry Trade 


\section{Introduction}

After the fall of socialism, formerly socialist countries undertook a series of reforms towards establishing functioning market economies. Most noteworthy of these reforms is the extensive trade liberalization. The purpose was to realign the domestic relative prices with world prices, and to resume international trade with their natural trade partners.

The initial opinion shared by many in Europe was that the liberalization efforts would not succeed: Transition countries were producing very few varieties of low quality goods that they could not possibly export to market economies. Contrary to this opinion, there has been a considerable reorientation of exports towards neighboring the European Union (EU) countries, especially in Central and East European countries (CEEC), away from their partners in Council for Mutual Economic Assistance (CMEA). Consequently, their export volume has significantly increased. This is considered as an important condition of successful transition as it implies significant restructuring of the production.

The natural question is the source of the increase in exports to market economies. According to Hummels and Klenow (2002), in general, an increase in export volume could be a result of three factors: Intensive margin, where the same set of goods is exported in larger volumes; extensive margin, where a larger set of goods is exported, and finally higher quality goods. The answer is critical in determining the extent of restructuring achieved, and thus the success of transitional reforms. Furthermore, the effects of each factor on countries' terms of trade and thus welfare are very different. Lastly, from a theoretical point of view, the answer is needed in determining the features of trade models that correspond better to data from transition countries. 
In an attempt toward an answer, the exports of CEEC and Commonwealth of Independent States (CIS) are analyzed in this paper. The focus is on their manufacturing exports to partners outside the former CMEA during 1992-99. CEEC and CIS countries are analyzed separately in groups and individually for comparison.

In section 2, potential export volumes of transition countries are computed with the help of gravity models. These are compared to actual volumes to measure the amount of reorientation. Then, the change in intensive margin of transition exports is computed to see how many of the same products exported under CMEA are reoriented to market economies. Lastly, the volume of total exports is decomposed into its inter-industry, horizontal and vertical intra-industry parts. Changes in each part are observed. Intraindustry exports have important implications for transition countries since it leads to growth by making markets bigger, and by disseminating technology. Cross-country and cross-sector comparisons of each part of exports conclude this section. The analysis shows that there have been significant increases in exports, but both CEEC and CIS exports were still below their potential as of 1999. There are considerable cross-country differences, in the amount and type of exports, as well as the amount of reorientation. Finally, not all of the increase is due to intensive margin, especially for CEEC, therefore, there is a need to analyze the changes in product differentiation and quality.

In Section 3, the degree of product differentiation in transition countries' exports is analyzed to measure its effect on the amount of reorientation. A number of measures of product variety from the literature are computed and discussed. These range from simple ones such as the number of product categories exported to more complicated ones of Funke and Ruhwedel (2001), and Hummels and Klenow's (2002) extensive margin. 
Lastly, their horizontal intra-industry exports based on product variety are measured, and CEEC and CIS countries are compared. The results show that the initial consequence of opening up to new trade partners is an increase in the number of products exported. This is followed by a brief period of specialization in certain products, and finally an increase in the number of varieties of these products. It is also found that the horizontal intraindustry exports have increased more significantly in CEEC than in CIS. Overall, the results suggest that an increase in product variety has been a more important factor in CEEC than in CIS in the amount of reorientation.

Various measures of quality are considered in section 4 to analyze the extent of the reorientation due to quality improvement. First, factor intensity of exports is studied. Then, some issues related to the use of unit values to proxy quality are briefly mentioned. The results from two different methods using unit values to analyze the extent of restructuring are discussed. Lastly, a quality index derived from Hummels and Klenow (2002) is computed for transition exports. The analysis shows that factor content of CEEC exports has become more human-capital intensive, whereas the share of such products has decreased in CIS exports. After a brief period of price competition, the aggregate unit values were increasing in CEEC, whereas CIS countries were not able to reverse the decreasing trend. The number of products under quality improvement in CEEC is more than triple the number in CIS. Calculations of Hummels-Klenow quality index show that although CIS started at lower quality exports, the quality has been increasing. Overall, these results suggest higher level of quality in CEEC exports, and higher rate of quality improvement. 
In sum, both CEEC and CIS have increased their exports to market economies significantly in a short period of time. However, the extent of reorientation has been smaller in the CIS. The analysis of changes in quantity, variety and quality shows that the reorientation in the CIS has been primarily due to increases in quantity, whereas increases in variety as well as increases in quantity have been important in CEEC. Although the quality of exports have been increasing in both groups of countries, the effect of quality upgrading on the extent of reorientation has been small for both.

\section{Reorientation of transition exports}

The data used in the analyses was obtained from International Trade Center of the UNCTAD/WTO. The time period immediately following the fall of socialism, 1989-91, is left out due to chaos and major economic problems of the time, especially in the CIS. Therefore, the analysis covers only the period of 1992-99. The trade of 22 transition countries with their non-traditional trade partners outside the CMEA is analyzed. ${ }^{1}$ These constitute the most important developed and developing partners with market economies. Exports to these countries constituted $97.3 \%$ of overall transition exports to all market economies of the world. The analysis focus primarily on manufacturing exports in SITC 5-8 sectors, which better fit the concepts of quality and variety addressed in this paper. CEEC and CIS countries are analyzed separately for comparison, given the different approaches they have taken in trade liberalization: Almost immediately after the collapse of the CMEA in 1991, ten CEEC signed the Europe Agreements with the EU. Five out of 12 CIS formed a customs union among themselves in $1994 .^{2}$ 
Figure 1 panel (a) shows the increase in transition countries' exports to market economies: Exports of CEEC almost tripled, increasing by 190\% during 1992-99. CIS exports increased slightly slower by $120 \%$ during the same period. The increase in CEEC exports has been steady, whereas it leveled off in CIS after 1995. Major EU countries dominated the CEEC exports, as well as smaller neighboring EU countries such as Austria. The same major EU countries, the US and Japan, as well as surrounding regional powers, such as Finland, Turkey and China had important places in CIS exports during this period. Given its relatively small size, Turkey's trade with Central Asian countries is striking. These results show the importance of economic size, distance, common language and common border.

\section{a. Actual and potential export volumes}

The reorientation of transition countries' exports towards market economies has been documented in a number of analyses: Winiecki (2000), Brenton and Gros (1997), Landesmann and Szekely (1995) for CEEC, Djankov and Freund (2002), and Kaminski (1996) for CIS can be counted among many. To answer whether the reorientation is complete or not, these studies used gravity models based on market economies. Gravity models are useful in finding the trade potential of countries by taking into account transportation costs, and demand and supply considerations with the help of distance, and GDPs of partner countries, respectively. In this paper, a gravity model with incomplete specialization that also includes common border and common language variables is used to find the export potential of transition countries in manufacturing to market economies. Haveman and Hummels (2001) found this model to be more consistent with data from 173 market economies. Figure 1 panel (b) gives the ratio of actual CEEC and CIS 
manufacturing exports to their potential. Although a significant amount of reorientation occurred in a short period of time, contrary to some earlier findings, reorientation of CEEC exports is found to be far from complete, at almost 60\% of its potential in 1999 . Reorientation of CIS exports has been less steady; it has been oscillating around 35\% of its potential since 1995. There are also significant cross country differences in reorientation. Table 1 column (1) gives actual exports as percentage of potential exports in 1992 and 1999 for individual countries. Accordingly, Hungary exceeded its potential by 1998. Kazakhstan and Romania's actual exports were about $90 \%$ of their potential in 1999. Bulgaria, Slovenia, and the Czech Rep. had exports about $32-50 \%$ of their potential at the beginning of the period analyzed, and had a relatively modest reorientation to 53$73 \%$ of their potential. Estonia, Lithuania and Latvia had much more significant reorientation, starting around $7 \%$ of their potential and ending at $69 \%, 45 \%$, and $38 \%$, respectively. CIS countries underperformed relative to CEEC. Although Russia started with the highest ratio of $18 \%$ in CIS, it ended with only $31 \%$ in 1999 . Kazakhstan, Moldova and Ukraine had the largest reorientation in CIS, increasing the ratio from around $2-10 \%$, to $90 \%, 58 \%$, and $42 \%$, respectively. The rest of the paper analyzes the changes in quantity, quality and variety of exports to understand why some countries were more successful in reorienting their exports than others.

\section{b. Changes in intensive margin}

This reorientation has been not entirely due to simply trading the same products exported under CMEA to market economies. This is evident from Figure 1 panel (c), where changes in intensive export margins for CEEC and CIS are calculated using Hummels and Klenow (2002). Figures for individual countries can be found in Table 1 
column (2). Intensive export margin computes the share of a country in the world exports of product categories in which it exports. To find whether the same products sold to CMEA members are being reoriented to market economies, the formula is slightly modified, and the amount of exports in the product categories where exports occurred in 1992 is analyzed. ${ }^{3}$ At time $t$, for country $A$, it is given as follows:

$H_{K I M_{t}^{A}}^{A}=\frac{\sum_{C} \sum_{p \in P_{92}^{A C}} X_{p t}^{A C}}{\sum_{C} \sum_{p \in P_{92}^{A C}} X_{p t}^{W C}}$

$P_{92}^{A C}=\left\{p \mid X_{p 92}^{A C}>0\right\}$

where $C$ is the set of market economies, $X_{p t}^{W C}$ is the world exports to a country in $C$ in product $p$ at time $t^{4}$ From the figure, it is seen that the changes in intensive margins are $69 \%$, and $63 \%$ for CEEC and CIS, respectively. When compared to a rate of increase in overall manufacturing exports of $190 \%$ in CEEC, and $120 \%$ in CIS, it becomes clear that other factors are also at play in reorientation of exports than selling the same products that were previously exported to CMEA members. ${ }^{5}$ It is noteworthy, however, that comparison of these figures implies selling the same products has been relatively much more important in CIS exports. This is also evident from the correlation coefficient between the rate of closing the gap between actual and potential exports, which are 0.87 and 0.53 for CIS and CEEC, respectively.

\section{c. Volume of different parts of exports}

Before looking for other factors to explain the reorientation, it is important to decompose the exports into its parts, and see how each has changed. This analysis will also help in determining the factors behind the reorientation. 
Inter-industry trade is a consequence of different factor endowments and the resulting specialization as predicted by Heckscher-Ohlin trade models. This is the most important type of trade between developed and developing countries. Intra-industry trade (IIT) has been significant between developed countries, as explained by the Increasing Returns Trade Theory built around the Krugman (1979) model. ${ }^{6}$

Intra-industry trade is composed of two significantly different parts. Horizontal IIT occurs when similar products are simultaneously exported and imported mainly due to product differentiation. Vertical IIT is defined by Grubel and Lloyd (1975) as the simultaneous export and import of goods in the same industry but at different stages of production. This results from vertical disintegration of production due to varying factor intensities within an industry.

A frequently used method to decompose IIT into its parts is based on ratio of unit values of exports. This technique has been criticized by the randomness in the choice of threshold ratio, which is used to determine whether IIT in an industry is vertical or horizontal. Therefore, a method based on the definitions for each part of IIT provided earlier is used in this study (Kandogan, 2003). This method uses values of exports and imports at two different levels of aggregation, where the higher level defines industries, and the lower level defines different products in each industry.

The method is slightly modified to find the export components of each part of trade. Using trade data at the higher level of aggregation, the total amount of intra-industry exports $\left(I I X_{i}\right)$ in each industry $i$ is computed by finding the amount of exports matched by imports. The unmatched part of total exports $\left(X_{i}\right)$ in the industry is inter-industry exports $\left(I N X_{i}\right)$. Then, the sum of matched exports in each product $p$ of industry $i$ is computed 
using data at the lower level aggregation. This gives the exports of similar products in an industry, i.e. horizontal intra-industry exports $\left(H I I X_{i}\right)$. The rest of the $I I X_{i}$ is the exports of different products within industry $i$, i.e. vertical intra-industry exports $\left(V I I X_{i}\right)$ :

$$
\begin{aligned}
& X=\sum_{i} X_{i}=\sum_{i} \sum_{p} X_{i p} \\
& I I X=\sum_{i} I I X_{i}=\frac{1}{2} \sum_{i} T T_{i}-\left|X_{i}-M_{i}\right| \\
& I N X=\sum_{i} I N X_{i}=\sum_{i} X_{i}-I I X_{i} \\
& H I I X=\sum_{i} H I I X_{i}=\sum_{i} \frac{1}{2} \sum_{p} X_{i p}+M_{i p}-\left|X_{i p}-M_{i p}\right| \\
& \text { VIIX }=\sum_{i} V I I X_{i}=\sum_{i} I I X_{i}-H I I X_{i}
\end{aligned}
$$

After a scrutiny of the definitions used in SITC classification, when decomposing total exports into its parts, 4-digit level is found to be appropriate to define products, and 2-digit level for industries. Figure 2 gives the trends in inter-industry, horizontal and vertical intra-industry exports of transition countries over the period analyzed. It is seen that the export volume of CEEC soared in the 1990s, with particularly strong increases in vertical and horizontal intra-industry exports. ${ }^{7}$ The situation in CIS is completely different. Almost of all the increase in exports has been inter-industry, whereas the increase in vertical and horizontal intra-industry exports has been very small. Analyzing countries individually, it can be seen that five Visegrad countries dominated the CEEC. 
Ukraine, Kazakhstan and Belarus were the most important countries in CIS. It is interesting that while Russia's inter-industry exports with its partners was the highest among all transition countries, it had relatively insignificant amount of horizontal and vertical intra-industry exports.

The volumes of different parts of exports in all nine sectors, both manufacturing and non-manufacturing, are also calculated for overall transition countries. Accordingly, more than half of exports in the manufacturing (SITC-6 and -8) and the machinery sector (SITC-7) were intra-industry, where the share of vertical IIX was almost equal to that of horizontal. Specialization was particularly strong in fuels, crude materials, and animal and vegetable oils sectors (SITC-0 through -4 ), where most of the trade was of interindustry type. This explains the earlier observation on Russia's exports. Overall, the IIX, especially HIIX, was more common in sectors where there is significant production differentiation such as manufacturing. It was insignificant, in sectors with standardized products such as natural resources, where most exports were inter-industry. ${ }^{8}$

The choice of partner also affects the type of exports. A big percentage of exports to developed market economies were IIX, with a bigger share in its horizontal part. IIX took only a small portion of trade with developing market economies, where the majority was vertical. This observation points out the role of different income levels, and relative factor endowments in explaining the volume of different components of exports. As countries become similar in factor endowments, inter-industry exports lose its dominance, and horizontal IIX become more important. Similarly, the choice of partner countries in liberalization agreements also affects the part of exports in which there will be increases, and consequently, the changes in quality and variety of a country's exports. 


\section{Product differentiation in transition countries}

This section focuses on increase in product differentiation as a possible cause for the reorientation of exports. A number of measures have been used for this purpose in the literature. The earliest measure suggested by Hufbauer (1970) is the ratio of the standard deviation of unit value of exports to its mean. This measure assumes a positive relationship between product differentiation and dispersion of prices. This method has been widely criticized since unit values are sensitive to changes in composition of trade and gives spurious evidence of product differentiation. Other researchers argue that since investment can stand for a proxy to resources devoted to production, it should act as an indirect indicator of product variety (Muscatelli et al., 1995). Some other authors have used output, profitability, $R \& D$ expenditures, and patents as indicators of product variety.

\section{a. Number of product categories}

This paper considers only the measures that use the widely available trade data. The simplest measure of product variety is the number of product categories in which a country exports. Figures 3 and 4 panel (a) give the total number of 4-digit level manufacturing products in which CEEC and CIS countries exported as a group to market economies, respectively. Note the N-shaped pattern in both groups of countries across time: Immediate response to trade liberalization was an increase in the number of products exported. This is most likely a result of the often-cited distressed-sale argument in the literature (Winiecki, 2000). This was followed by a short period of decrease, after which the number of products exported leveled off. Trade liberalization obviously opened 
doors to firms that would like to test their mettle in the world markets. But, not all of them were successful. An adjustment eventually occurred, and countries specialized in fewer of products. Figures for individual countries are listed in Table 1 column (3), where it is observed that the number of products exported by an individual country in CEEC was much higher than that by a CIS country.

Despite the advantage of its easiness, a simple count of product categories treats small and large product categories the same. This measure also ignores possible differentiation within a product category. This is reflected to correlation coefficients between the change in the number of product categories and the rate of closing the gap between actual and potential exports, which are insignificant (0.17) for CIS, and low but significant $(0.34)$ for CEEC. Higher coefficient for CEEC suggests that an increase in number of product categories exported has been more important for CEEC than CIS.

\section{b. Funke-Ruhwedel index}

The second measure considered is an alternative interpretation of the approach taken in Funke and Ruhwedel (2001). It has close links to Feenstra (1994), and Feenstra and Markusen (1996). While Funke and Ruhwedel's original measure (FR) relies on CES production function, this one relies on CES utility functions. It is also further modified so that the increase in product variety from one year to the next can be computed rather than the increase relative to a base year. Accordingly, the change in product variety in a country $A$ from time period $t-1$ to $t$ is given as follows: 
$F R_{t}^{A}=\ln \left(\frac{\sum_{p \in P_{t}} X_{p t}^{A} / \sum_{p \in P} X_{p t}^{A}}{\sum_{p \in P_{t-1}} X_{p t-1}^{A} / \sum_{p \in P} X_{p t-1}^{A}}\right)$

$P_{t}=\left\{p \mid X_{p t}^{A}>0\right\}, P_{t-1}=\left\{p \mid X_{p t-1}^{A}>0\right\}$, and $P=P_{t-1} \cap P_{t}$

where $X_{p t}^{A}$ is the volume of exports of country $A$ in product $p$ at time $t$.

This measure finds the difference between the change in the volume of exports in all products in two consecutive time periods, and the increase in the volume of exports in common products that were exported at both time periods. The difference is the increase in the volume of other products traded.

This measure better deals with differences in the size of product categories than the simple count of product categories, since it is based on the volume of trade instead of the number of products. However, it has shortcomings: In the absence of highly disaggregated data, all of the increase in volume of products commonly traded in two consecutive periods is subtracted, therefore assumed to be an increase in the volume of the same product variety. However, this may very well be due to an increase in product variety in that product category. Therefore, this measure may understate the increase in product variety.

Figures 3 and 4 panel (b) give the FR index averaged over all CEEC and CIS, respectively, where the weights are each country's export shares. The N-shaped pattern observed in the number of product categories is somewhat repeated. However, the period of specialization is more pronounced. This implies that transition countries were no longer able to export varieties of products in large product categories, and most of the specialization observed occurred in product categories with low trade volume. The change in this index between 92 and 99 for individual countries can be found in Table 1 
column (4). Especially for CEEC, this index does not capture the increase in variety within product categories. Evidently, the correlation coefficient between the rate of closing gap between actual and potential exports, and the change in this index is insignificant and negative for both CIS and CEEC (-0.19 and -0.04, respectively). At the given level of aggregation, this index performed poorly to capture the changes in variety.

\section{c. Hummels-Klenow extensive margin}

The third measure considered is Hummels and Klenow's (2002) extensive margin. The extensive margin measures the fraction of the world exports that occur in the product categories in which that a country exports to its partners. This is the export version of Feenstra's (1994) measure of import variety. The logic is that if a country's exports are concentrated in a small number of products, it will have low extensive margin, implying few product varieties. For country $A$ at time $t$, it is computed as follows:

$\operatorname{HKEM}_{t}^{A}=\frac{\sum_{C} \sum_{p \in P_{t}^{A C}} X_{p t}^{W C}}{X_{t}^{W}}$

$P_{t}^{A C}=\left\{p \mid X_{p t}^{A C}>0\right\}$

where $X_{t}^{W}$ is the overall world manufacturing exports at time $t$.

In this measure, the weight of each product category is different -its share in world exports- therefore, large product categories are better represented than they were in simple count of product categories. It also has an advantage over the FR index: Highly disaggregated data is not needed as much since it already captures the increase in product differentiation within a product category. However, it may overstate the increase in product differentiation, since it considers all of the increase in exports in a product 
category as an increase in the number varieties. It may also overstate the extensive margin of a country, since the weight used for each product category is its share in world exports, rather than its share in that country's exports.

Figures 3 and 4 panel (c) give the HKEM indexes for CEEC and CIS, respectively. Changes in extensive margin during the period of analysis for individual countries are listed in Table 1 column (5). The same N- shaped pattern is again observed, but the product variety no longer levels off after specialization. In fact, an increase is observed, which can be interpreted as an increase in the number of varieties of the products that transition countries have specialized. The increase in extensive margin has been much

more significant in CEEC. In particular, the correlation coefficient between the rate of closing the gap between actual and potential exports is 0.45 for CEEC, and an insignificant but positive figure of 0.16 for CIS. This further supports the earlier result that the increase in variety has been much more important factor for CEEC than for CIS.

\section{d. Horizontal intra-industry exports}

Lastly, considering the close relationship between product differentiation and horizontal intra-industry exports, HIIX is used to measure the extent of product differentiation. HIIX is the export part of the simultaneous trade of varieties of basically the same product category. Thus, not all of the increase in exports within a product category is labeled as an increase product differentiation as was the case in HKEM in the absence of highly disaggregated data.

Figures 3 and 4 panel (d) give horizontal intra-industry exports of CEEC and CIS, respectively. HIIX for individual countries in 1992 and 1999 can be found in Table 1 column (6). Accordingly, the HIIX in CEEC more than tripled during the period of 
analysis, whereas CIS experienced less than 25\% increase in HIIX. When increases in manufacturing exports and HIIX are compared individually for each country, it can be seen that the majority of the increase in manufacturing exports to market economies in CEEC is due to an increase in product variety. This is especially strong in the Czech Rep., Poland, and Hungary, whereas it is much smaller in Bulgaria, Lithuania, and Latvia. This can be the result of substantial FDI flows to CEEC as mentioned in Aturupane et al. (1999). The situation is very different in CIS exports: Although the amount of horizontal intra-industry exports in the Russian Fed. is the highest, there has been a decrease. The highest increases are observed in Kazakhstan, Ukraine and Belarus. However, even for these countries, only a small portion of the increase in their exports is due to product differentiation. The situation is much worse in other CIS. This measure shows once again that product differentiation played little role in the trade reorientation of CIS countries and it has been very important for CEEC.

\section{Quality of transition countries' exports}

The literature before the collapse of socialism provides numerous accounts for the lack of quality in Eastern Europe's manufacturing exports (van Brabant, 1988; Bogomolov, 1987; Treml, 1981). The US-imposed embargo on exports of strategic and high technology goods to communist economies in 1947 can be counted as one of the important causes for this situation (van Brabant, 1980). However, the trade block formed

in response among socialist countries in 1949, the Council for Mutual Economic 
Assistance (CMEA), where there were no incentives for innovation, is considered by many as the primary reason for the low quality of Eastern European products.

To be able to export their manufacturing products, transition countries needed to improve the quality of their products through restructuring. In this section, the amount of restructuring, and quality improvement is studied.

\section{a. Factor intensity of exports}

One way to find out about the changes in quality of products is to look at the production technology. Changes in the factor content of production reveal the amount technological improvement and thus the extent of restructuring. Under CMEA, the factor used intensively in transition countries' exports was primarily natural resources. A move towards human and physical capital intensive production would therefore imply significant restructuring. To analyze the factor content of the transition countries' exports with market economies, the quality ladders of Wolfmayr-Schnitzer (1998) are used. Accordingly, the quality of production increases in the following order: Resource intensive, human capital intensive- low technology, labor intensive, human capital intensive-medium technology-labor intensive, human capital intensive-medium techcapital intensive, human capital intensive-high technology- labor intensive, and human capital intensive-high technology-capital intensive. For simplicity, the last four categories are aggregated into human-capital intensive high quality products.

Figures 5 and 6 panel (a) give the amount of total (X) and human-capital intensive (HCX) amount of manufacturing exports of CEEC and CIS to market economies during 1992-99. Figures for individual countries are listed in Table 1 column (7). Accordingly, HCX in CEEC more than tripled, whereas it increased only slightly in CIS. 
Consequently, all CEEC experienced increases in the share of HCX except for relatively labor abundant countries in CEEC (Bulgaria, Romania, Latvia, and Lithuania). ${ }^{9}$ This is primarily due to increases in the share of labor intensive exports in these four countries, as a result of outward processing trade arrangements in the Europe Agreements for labor intensive sectors of clothing and footwear (SITC 841, 842, 851). Share of HCX ranged from $9 \%$ to $17 \%$ in these four countries in 1999 . It was $29 \%$ in Poland, $51 \%$ in Hungary, and was between $39 \%$ and $46 \%$ in other CEEC. A decreasing trend in the share of HCX was more common in CIS, except in Kazakhstan, and Belarus. In 1999, the share of CIS was much smaller than those for CEEC. This is also captured by the correlation coefficient between increases in HCX and the rate of closing the gap between actual and potential exports. The figures are positive and significant for both CIS and CEEC, but much higher in CEEC (0.39 and 0.52, respectively).

\section{b. Unit values of exports}

Although an examination of factor intensity of exports gives a general idea about the extent of restructuring, not much can be inferred about the response of individual sectors to competition from market economies due to the amount of aggregation involved. Unit values provide a better and more frequently used tool to measure quality changes.

The unit value of exports is defined as the dollar value of exports in a given commodity category divided by its quantity. Since quantity units can be different than the number of products, unit value might be different from unit price. Lipsey (1963), and Kravis and Lipsey (1971) have shown that unit value indexes can be poor substitutes for price indexes. Several reasons have been forwarded to explain this inadequacy of unit values: According to Enoch (1978), and Maciejewski (1983), the most important reason 
is that a change observed in unit values may simply be a reflection of changes in the composition of goods within a class of products.

According to Aiginger (1998), and Landesmann and Burgstaller (1998), rather than price, unit value reflects quality for a number of reasons. First, if the products are similar, the prices that consumers are willing to pay must reflect differences in the consumers' perception of the quality of the products. Second, higher quality products embody a greater proportion of factors that do not make a corresponding contribution to the weight of the product, such as human capital and better technology.

Aiginger (1998) further argues that as a country's output moves up the quality ladder, the unit value of that country's aggregate exports of manufactures increases. Consequently, differences in the unit value of aggregate exports can be taken as an approximation of the relative quality difference. Aggregation that was a disadvantage in comparison of prices, turns out to be an advantage in comparing the quality of products.

It should be noted that decreasing unit values is not always a sign of distressed trade resulting from structural problems. When competing internationally, the technologically superior partner can retain its competitiveness by increasing quality, and the inferior one can stay competitive by lowering production costs..$^{10}$

Thus, transition countries can engage in either price competition and sell their low quality products, or try to improve the quality by restructuring. The difference is that industrial restructuring cannot happen instantaneously, but price competition can. ${ }^{11}$ Given the initial conditions, transition countries are expected to initially engage in more price competition than quality improvement, and thus the aggregate unit values will initially decrease. They will gradually overcome this initial disadvantage through changes in the 
economic environment, and move up the quality ladder. Thus, there will be increases in the quality of some products and/or the proportion of products with higher quality due to restructuring. This reasoning implies U-shaped aggregate unit values.

This is what is observed in Figure 5 panel (b), where the aggregate unit value of exports for CEEC is plotted. ${ }^{12}$ Percentage changes for individual countries are in Table 1 column (8). When sectors and countries are analyzed separately, it is observed that in the chemicals sector (SITC-5), price competition is widespread. Quality improvement is common in other sectors: In the manufacturing sector (SITC-6), all CEEC experienced increases in the unit values. In the machinery and miscellaneous manufacturing sectors (SITC-7 and 8), the unit values increased for the majority of CEEC. Hungary experienced decreases in both sectors. Slovenia experienced a decrease in only miscellaneous manufacturing. In the machinery sector, Slovenia, the Czech and Slovak Republics eventually turned the decreasing trend upwards.

Decreasing unit values are much more common in CIS, as can be seen from Figure 6 panel (b). However, when sectors are analyzed individually, the U-shaped unit values are commonly observed in the machinery sector. Increasing unit values are observed in the manufacturing sector for the majority of the CIS countries.

Next, an analysis of the unit values in each product category across time is carried out to obtain the number of products under quality improvement. For this purpose, each year, the products that reverse the decreasing trend are added to the list of products under quality improvement. If there is an increasing trend in the unit value for a product category for the whole time period, it is considered to be already under quality improvement since 1993. The difference between CIS and CEEC is once again striking, 
as seen in Figures 5 and 6 panel (c). The number of products under quality improvement in 1992 and 1999 for individual countries are listed in Table 1 column (9). The number in CEEC is more than triple the number in CIS. Furthermore, more than $30 \%$ of products exported by CEEC were under quality improvement in 1993, and almost all CEEC surpassed $40 \%$ by the end of 1999, lead by the Czech Republic, and Poland. Although started at lower levels, Slovenia, and Hungary had the faster increases in the number of products under quality improvement. Baltic States of Lithuania, Estonia and Latvia, started at the lowest levels, and had the lowest rate of increase. In contrast, in all CIS except Russia, Ukraine and Belarus, the percentage of traded products under quality improvement remained below $15 \%$ for the entire period of analysis. In these three countries, the rate of increase was comparable to that in CEEC. Kazakhstan, Georgia, and Moldova had modest increases in the percentage. The increase in other CIS can be considered negligible. The insignificant but positive correlation coefficients between the increases in the number of products under quality improvement and the rate of closing the gap suggest stronger effects of other factors on the rate $(0.01$ for CEEC, and 0.06 for CIS). According to the analysis so far, that factor could be increases in variety for CEEC and increases in quantity for CIS. In fact, Landesmann and Szekely (1995) find significant increases in quality of three largest CEEC earlier, during 1988-1991. In any further closing gap in CEEC, increases in variety can be more important.

\section{c. Hummels-Klenow quality index}

The last measure of quality is derived from Hummels and Klenow (2002). It is based on an Armington model with endogenous choice of quality, where relative demand is 
decreasing in quality adjusted prices. The quality of exports of country $A$ relative to country $B$ at time $t$ is given as follows:

$$
H K Q_{t}^{A}=\left(\frac{H K p_{t}^{A}}{H K p_{t}^{B}}\right)\left(\frac{H K q_{t}^{A}}{H K q_{t}^{B}}\right)
$$

where $H K p_{t}^{A}$ and $H K q_{t}^{A}$ are price and quantity indexes for country $A$ at time $t$ :

$$
\begin{aligned}
& H K p_{t}^{A}=\frac{\sum_{C} \sum_{p \in P_{t}^{A C}} X_{p t}^{A C}}{\sum_{C} \sum_{p \in P_{t}^{A C}} p_{p t}^{W C} q_{p t}^{A C} \frac{\sum_{C} \sum_{p \in P_{t}^{A C}} p_{p t}^{A C} q_{p t}^{W C}}{\sum_{C} \sum_{p \in P_{t}^{A C}} X_{p t}^{W C}}} \\
& H K q_{t}^{A}=\frac{\sum_{C} \sum_{p \in P_{t}^{A C}} X_{p t}^{A C}}{\sum_{C} \sum_{p \in P_{t}^{A C}} p_{p t}^{A C} q_{p t}^{W C}} \frac{\sum_{C} \sum_{p \in P_{t}^{A C}} p_{p t}^{W C} q_{p t}^{A C}}{\sum_{C} \sum_{p \in P_{t}^{A C}} X_{p t}^{W C}} \\
& P_{t}^{A C}=\left\{p \mid X_{p t}^{A C}>0\right\}
\end{aligned}
$$

Both of these are Fisher Ideal indexes, which are widely used for constructing price and quantity indexes. It must be noted that the factor of these price and quantity indexes gives the intensive margin.

To correctly capture the changes in quantity of a country $A$, the base country $B$ must be a small country, where there has not been much changes in the quality of its exports. Based on the previous quality measures, Azerbaijan is chosen for this purpose. ${ }^{13}$ Figures 5 and 6 panel (d) gives the quality indexes for CEEC and CIS relative to Azerbaijan. Changes during the period of analysis for individual countries can be found in Table 1 column (10). Note that the same U-shaped pattern is observed for both groups of countries. The CIS countries experienced larger increases in quality of their exports 
relative to Azerbaijan than CEEC. This is expected since they started at much lower quality than the CEEC. The correlation coefficients between changes in this index and the rate of closing gap support this conclusion, which are insignificant for both CEEC and CIS (0.01 and 0.24, respectively).

In sum, both CEEC and CIS experienced improvements in quality of their exports. However, the increase in quality is observed in labor intensive products in CIS as their exports are becoming more labor intensive. However, due to the composition of their exports, a decrease in aggregate unit values is observed. In contrast, CEEC exports are becoming increasingly human capital intensive, and their aggregate unit values are rising.

Overall, the quality of exports of CEEC is much higher than those of CIS. However, the change in quality has been the least important in closing the gap among other factors considered in this paper.

\section{Conclusions}

There has been considerable amount of increase in the exports of transition countries' to market economies. Especially CEEC was successful in reorienting their exports as their share of actual exports reached almost $60 \%$ of its potential by 1999 . However, there is a considerable amount of differences in the extent of this reorientation across countries in both CEEC and CIS. This paper analyzed the changes in quantity, variety and quality of transition exports to market economies using a variety of measures from the literature to determine the factors behind these cross-country differences. 
Analysis of intensive margin by Hummels and Klenow (2002) shows that simply exporting the products that were previously traded under CMEA to market economies cannot be the only reason behind the extent of the reorientation. However, it is found that it had a much more significant effect on CIS exports than CEEC exports.

A variety of different measures are used in analyzing changes in product differentiation. Each measure has its advantages and shortcomings, each revealed different but important pieces of information. Analyzing the number of product categories in which transition countries exported showed that firms respond to liberalization by first testing their mettle in world markets. However, only those in certain industries succeeded, which lead to specialization on certain product categories. Funke and Ruhwedel's index showed that most of this specialization occurred in small product categories. Extensive margin index of Hummels and Klenow revealed that, in fact, there was an increase in variety in product categories in which the transition countries specialized. These observations suggest $\mathrm{N}$-shaped changes in variety of transition exports. Last, but not least, an analysis of horizontal intra-industry exports revealed that CEEC has been much more successful in product differentiation than CIS, and that had a bigger impact on the rate of closing the gap between actual and potential exports for CEEC.

Furthermore, it is observed that the absence of highly disaggregated data causes some indexes to perform poorly. In such circumstances, Funke-Ruhwedel index underestimates the degree of product differentiation, considering all changes in a product category as increase in exports of the same product variety. Contrarily, Hummels and Klenow extensive margin overestimates it, considering all changes in a product category as 
increase in product differentiation. In the case of transition countries, however, the latter performed better.

Analysis of quality upgrading and restructuring reveal that although CEEC countries as a whole have higher quality products and were able improve the quality better than CIS, the changes in quality were not significant enough to have an effect on the rate of closing the gap between actual and potential exports for both groups of countries.

The better results for CEEC than CIS are partly consequences of the liberalization agreements as suggested by analysis of different parts of exports. The Europe Agreements forced CEEC to compete with market economies. In conjunction, they have received the largest FDI among all emerging markets. Prosi (1998) argues that technology transferred by FDIs to CEEC meets the factor proportions and skills of advanced economies, not those of labor intensive economies. These factors caused CEEC to perform much better than the CIS in both increasing product variety and improving the quality of their exports. On the other hand, the CIS customs union does not lead to either of these since it does not encourage trade with market economies. It is an attempt to preserve the status quo under CMEA.

Although CEEC's achievements are better, they too underperformed. There is still a need to improve the quality of their products. Simple tariff cuts by the Europe Agreements are apparently insufficient to do this. In fact, given their factor abundance relative to the EU, the Europe Agreements forced some CEEC to specialize in labor intensive low quality products. Although Martin (1998) considers this potential for maquiladora syndrome unlikely for more advanced countries such as the Czech Republic, Poland and Hungary, substantial increases in exports of labor-intensive products from 
Bulgaria, Romania, Latvia and Lithuania found in this paper should be noted with caution. In this context, it can be said that largely reported high skill in some of these CEEC is either overestimated or not yet exploited. Rosati (1998) proposes the lack of capital as the leading cause. FDI was high, but considering how obsolete their capital was after the fall of socialism, it apparently was not enough.

\section{References}

Aiginger, Karl, 1998. Unit Values to Signal the Quality Position of CEECs. In The Competitiveness of Transition Economies, OECD Proceedings, 15-40.

Aturupane, Chonira, et al., 1999. Horizontal and Vertical Intra-industry Trade between Eastern Europe and the European Union. Weltwirtschaftliches Archiv 135(1): 62-81.

Bogomolov, Oleg, 1987. The Socialist Countries at a Critical Stage in World Economic Development. Problems of Economics 30 (8): 38-54.

Brenton, Paul, and Gros, Daniel, 1997. Trade Reorientation and Recovery in Transition Economies. Oxford Review of Economic Policy 13(3): 65-76.

Davis, Donald R, 1995. Intra-industry Trade: A Heckscher-Ohlin Ricardo Approach. Journal of International Economics 39(3-4): 201-26.

Djankov, Simeon, and Freund, Caroline, 2002. Trade Flows in the Former Soviet Union, 1987 to 1996. Journal of Comparative Economics 30 (1): 76-90.

Djankov, Simeon, and Hoekman, Bernard, 1996. Intra-industry trade, Foreign Direct Investment and the Reorientation of East European Exports. Centre for Economic Policy Research, Discussion Paper 1377. 
Drabek, Zdenek, and Smith, Alasdair, 1995. Trade Performance and Trade Policy in Central and Eastern Europe. CEPR Discussion Paper 1182.

Enoch, C. A., 1978. Measures of Competitiveness in International Trade. Bank of England Quarterly Bulletin 18: 181-95.

Feenstra, Robert, 1994. New Product Varieties and the Measurement of International Prices. American Economics Review 84(1): 157-77.

Feenstra, Robert, and Markusen, James, 1996. Accounting for Growth with New Inputs. International Economic Review 35(2): 429-447.

Funke, Michael, and Ruhwedel, Ralf, 2001. Product Variety and Economic Growth Empirical Evidence for the OECD Countries. IMF Staff Papers 48(2): 225-242.

Grossman, Gene, and Helpman, Elhanan, 1991. Quality Ladders and Product Cycles. Quarterly Journal of Economics 106(2): 557-86.

Grubel, Herbert G., and Lloyd, Peter J., 1975. Intra-industry Trade: The Theory and Measurement of International Trade in Differentiated Products, London.

Haveman, Jon, and Hummels, David, 2001. Alternative Hypotheses and the Volume of Trade: the Gravity Equation and the Extent of Specialization. Purdue University Center for International Business Education and Research, Working Paper 2000-04.

Hufbauer, Gary, 1970. The Impact of National Characteristics and Technology on the Commodity Composition of Trade in Manufactured Goods. In Vernon, Roningen, (Ed.) The Technology Factor in International Trade. New York: Columbia University Press.

Hummels, David, and Klenow, Peter, 2002. The Variety and Quality of a Nation's Trade. NBER Working Paper No. 8712. 
Kaminski, Bartlomiej, 1996. Factors Affecting Trade Reorientation of the Newly Independent States. In Kaminski, Bartlomiej, (Ed.) Economic Transition in Russia and the New States of Eurasia. International Politics of Eurasia Series 8. New York and London: Sharpe.

Kandogan, Yener, 2003. Reconsidering the Adjustment Costs of the Europe Agreements. Applied Economics Letters 10(2): 63-8.

Kravis, Irving, and Lipsey Robert, 1971. International Trade Prices and Price Proxies. In Ruggles, Nancy (ed.), The Role of the Computer in Economic and Social Research in Latin America, NBER, New York.

Krugman, Paul R., 1979. Increasing Returns, Monopolistic Competition, and International Trade. Journal of International Economics 9: 469-79.

Landesmann, Michael, and Burgstaller, Johann, 1998. Vertical Product Differentiation in EU Markets: The Relative Position of East European Producers. In The Competitiveness of Transition Economies, OECD Proceedings.

Landesmann, Michael, and Szekely, Istvan, 1995. Industrial Restructuring and Trade Reorientation in Eastern Europe. University of Cambridge Department of Applied Economics Occasional Paper 60.

Lipsey, Robert, 1963. Price and Quantity Trends in the Foreign Trade of the United States, Princeton University Press, Princeton.

Maciejewski, E. B., 1983. Real Effective Exchange Rate Indexes -a Reexamination of the Major Conceptual and Methodological Issues. IMF Staff Papers 30: 491-541.

Martin, R., 1998. Central and Eastern Europe and the International Economy: The Limits to Globalization. Europe-Asia Studies 50(1): 7-26. 
Muscatelli, Antonio., et al., 1995. Modeling Aggregate Manufactured Exports for Some Asian Newly Industrialized Economies. Review of Economics and Statistics 77(1): $147-155$.

Prosi, Gerhard, 1998. Economic Cooperation between Members of the European Union and New Democratic Countries of Europe Communist Economies and Economic Transformation 10(1): 111-18.

Rosati, Dariusz, 1998. Emerging Trade Patterns of Transition Countries: Some Observations from the Analysis of Unit Values. MOCT-MOST 8: 51-67.

Sheets, Nathan, and Boata, Simona, 1998. Eastern European Export Performance during the Transition. Contemporary Economic Policy 16: 211-26.

Treml, Vladimir, 1981. Inferior Quality of Soviet machinery as Reflected in Export Prices. Journal of Comparative Economics 5: 200-21.

van Brabant, Jan, 1988. Production Specialization in the CMEA: Concepts and Empirical Evidence. Journal of Common Market Studies 26(3): 287-315.

van Brabant, Jan, 1980. Socialist Economic Integration, Cambridge University Press, Cambridge.

Winiecki, Jan, 2000. Successes of Trade Reorientation and Expansion in PostCommunist Transition: An Enterprise Level Approach. Banca Nazionale del Lavoro Quarterly Review 53(213): 187-223.

Wolfmayr-Schnitzer, Yvonne, 1998. Trade Performance of CEECs According to Technology Classes. In The Competitiveness of Transition Economics, OECD Proceedings:81-92. 

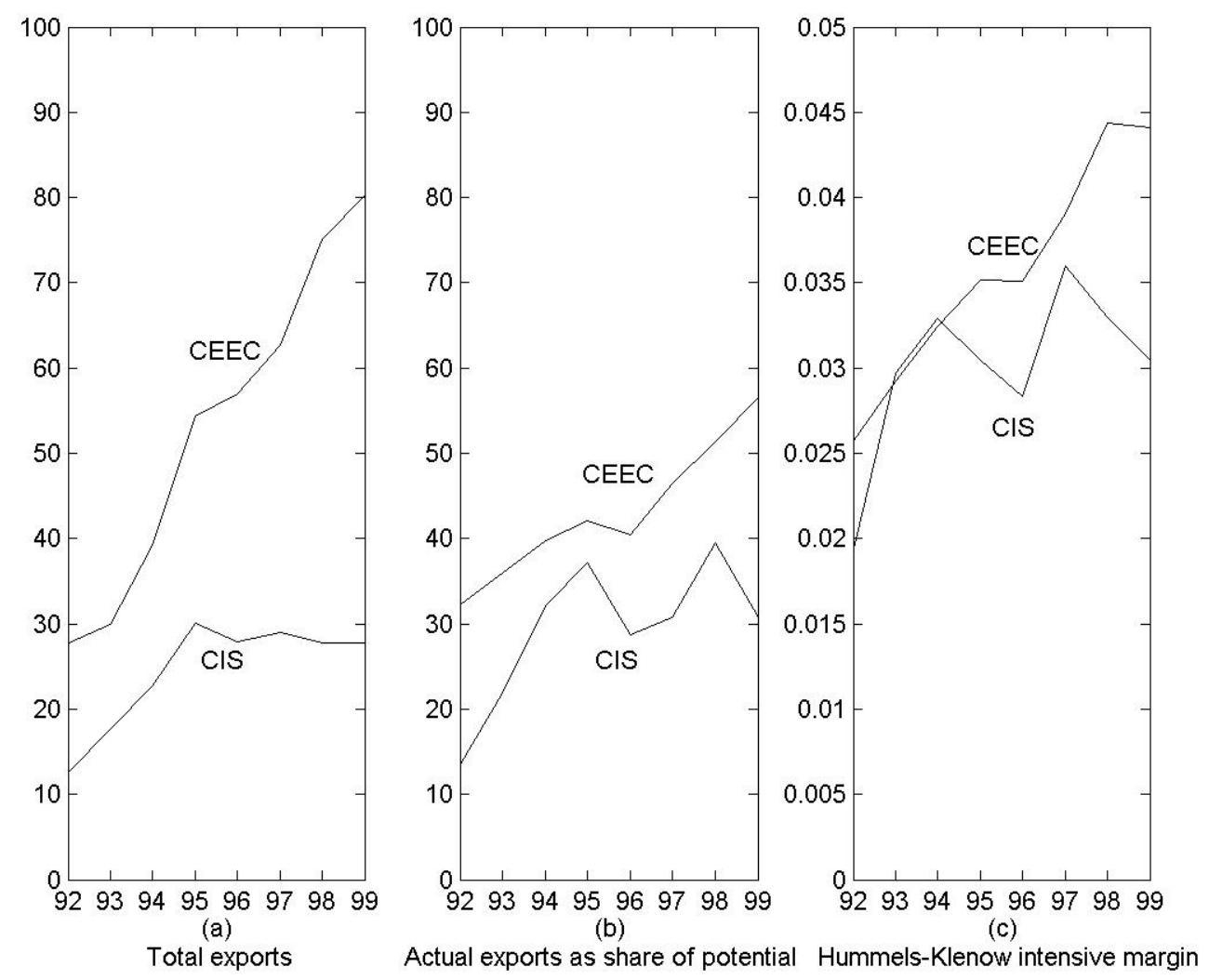

Figure 1. Exports, its share in potential, and its intensive margin Total exports are given in billions of US\$. 

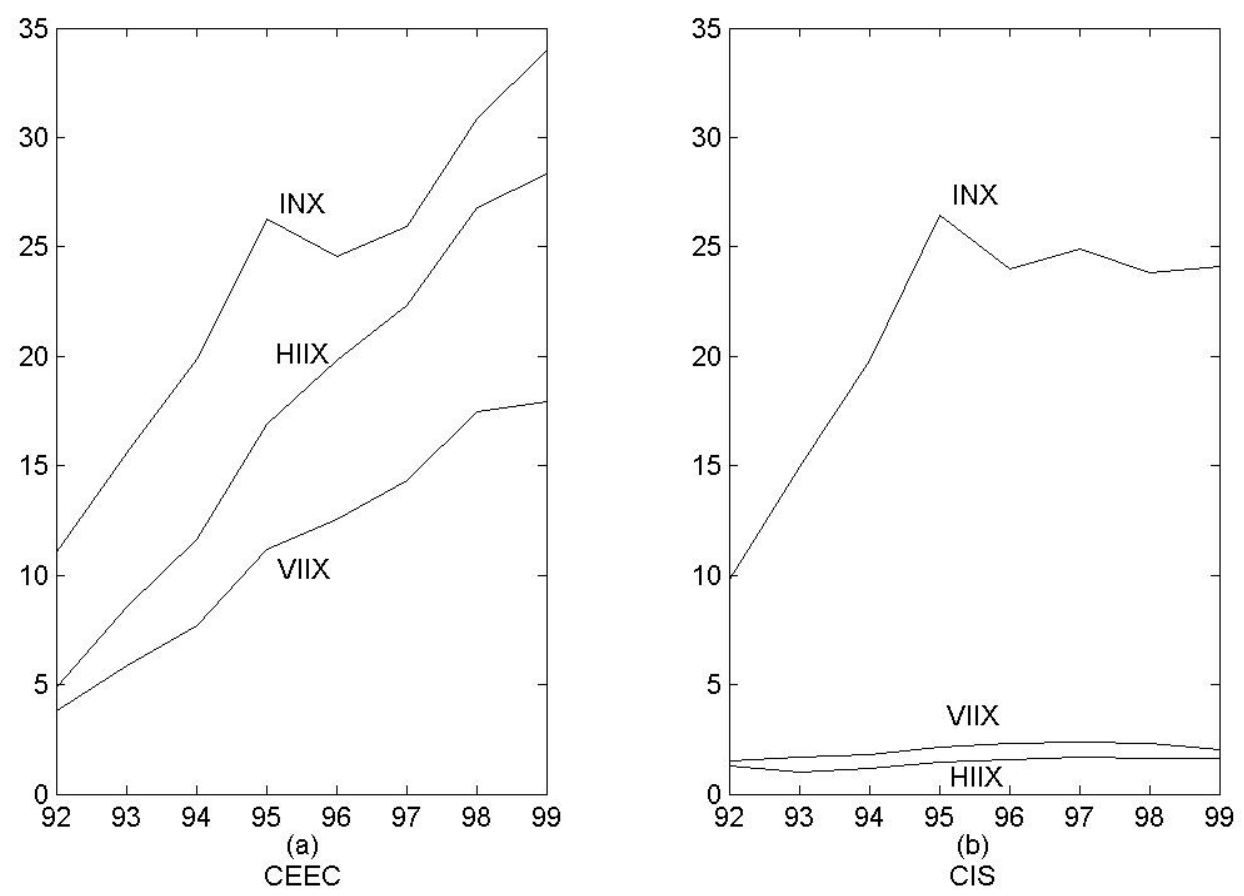

Figure 2. Parts of transition exports

Each part of exports are given in billions of US\$. 


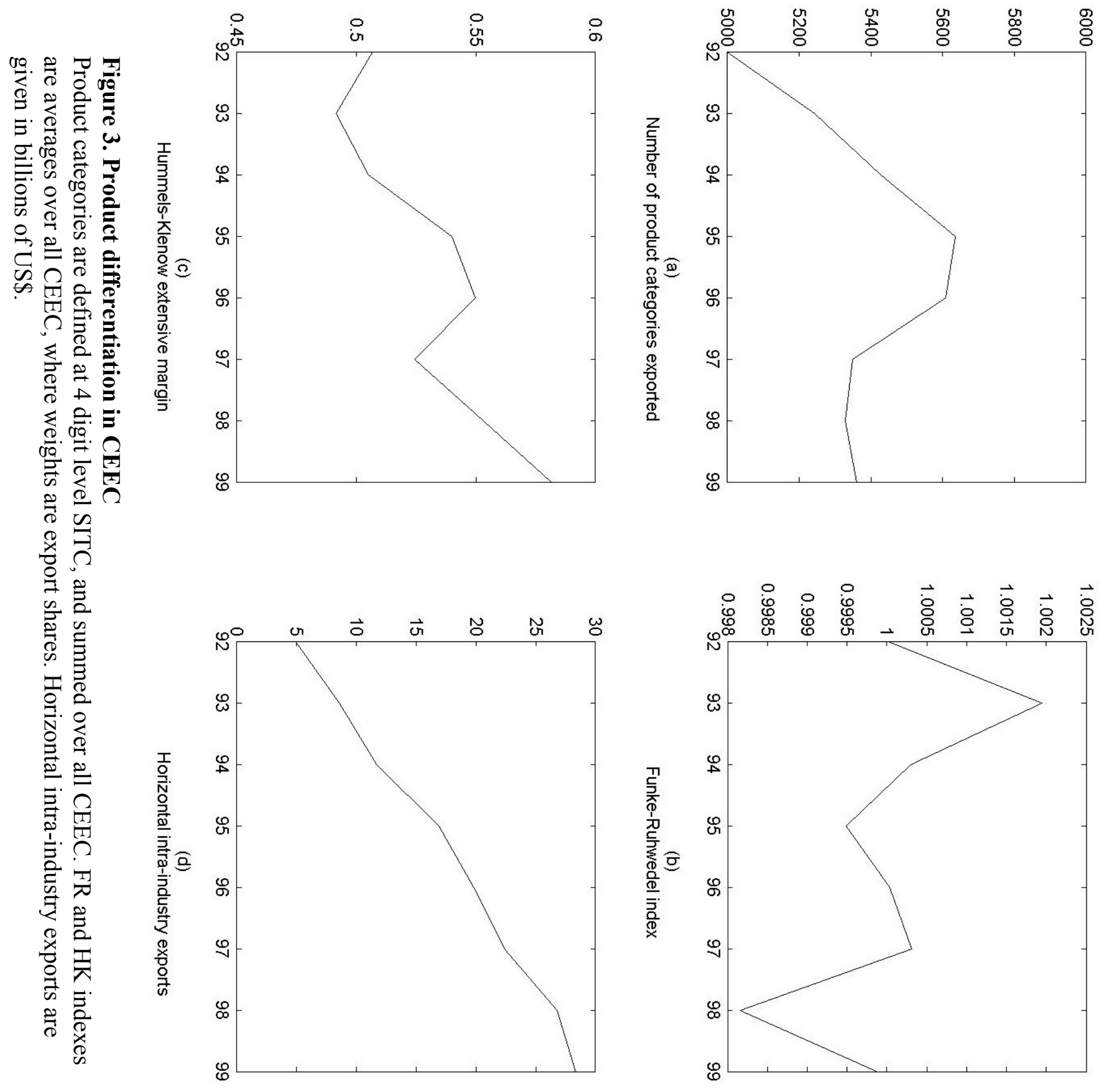




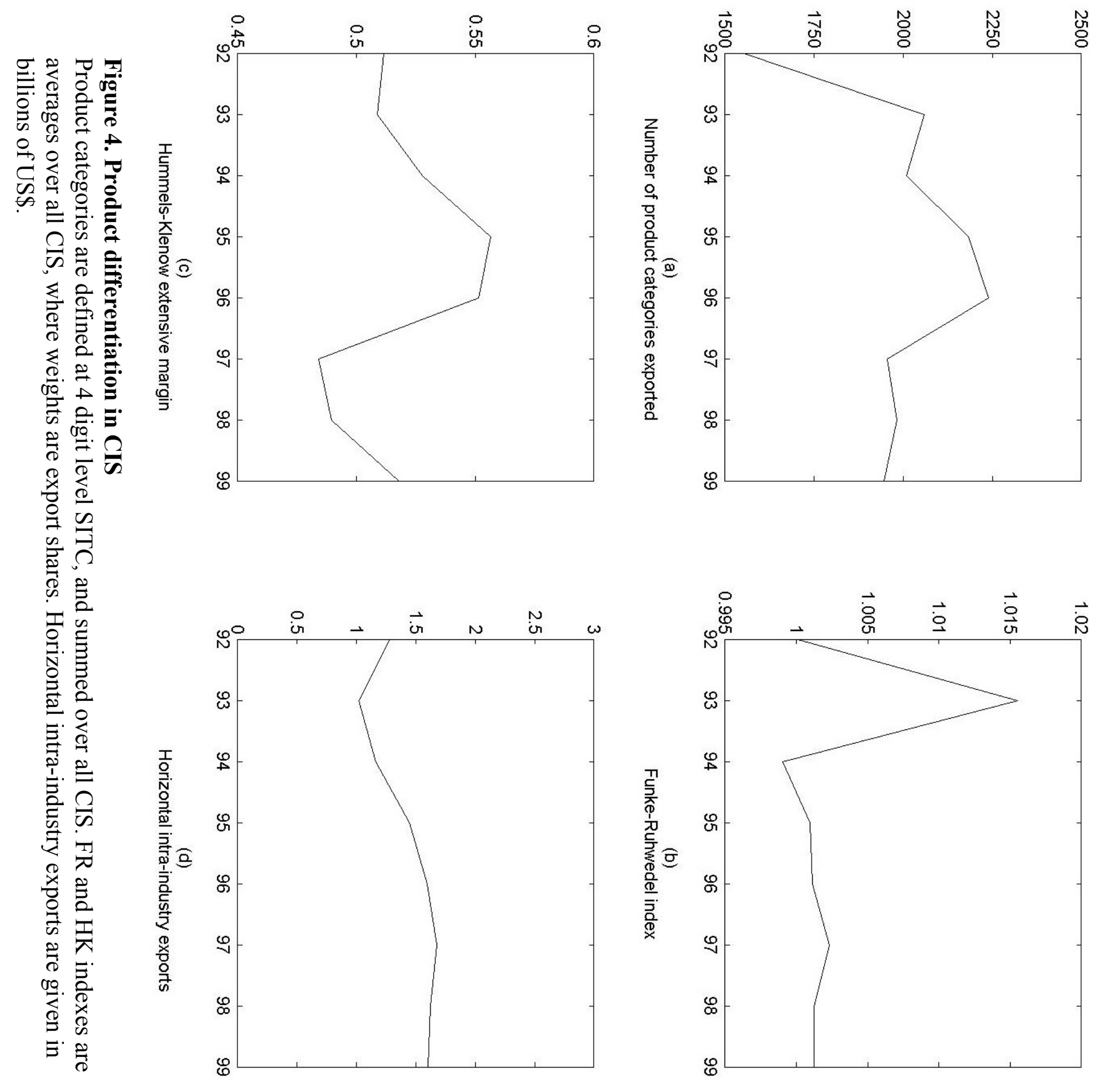




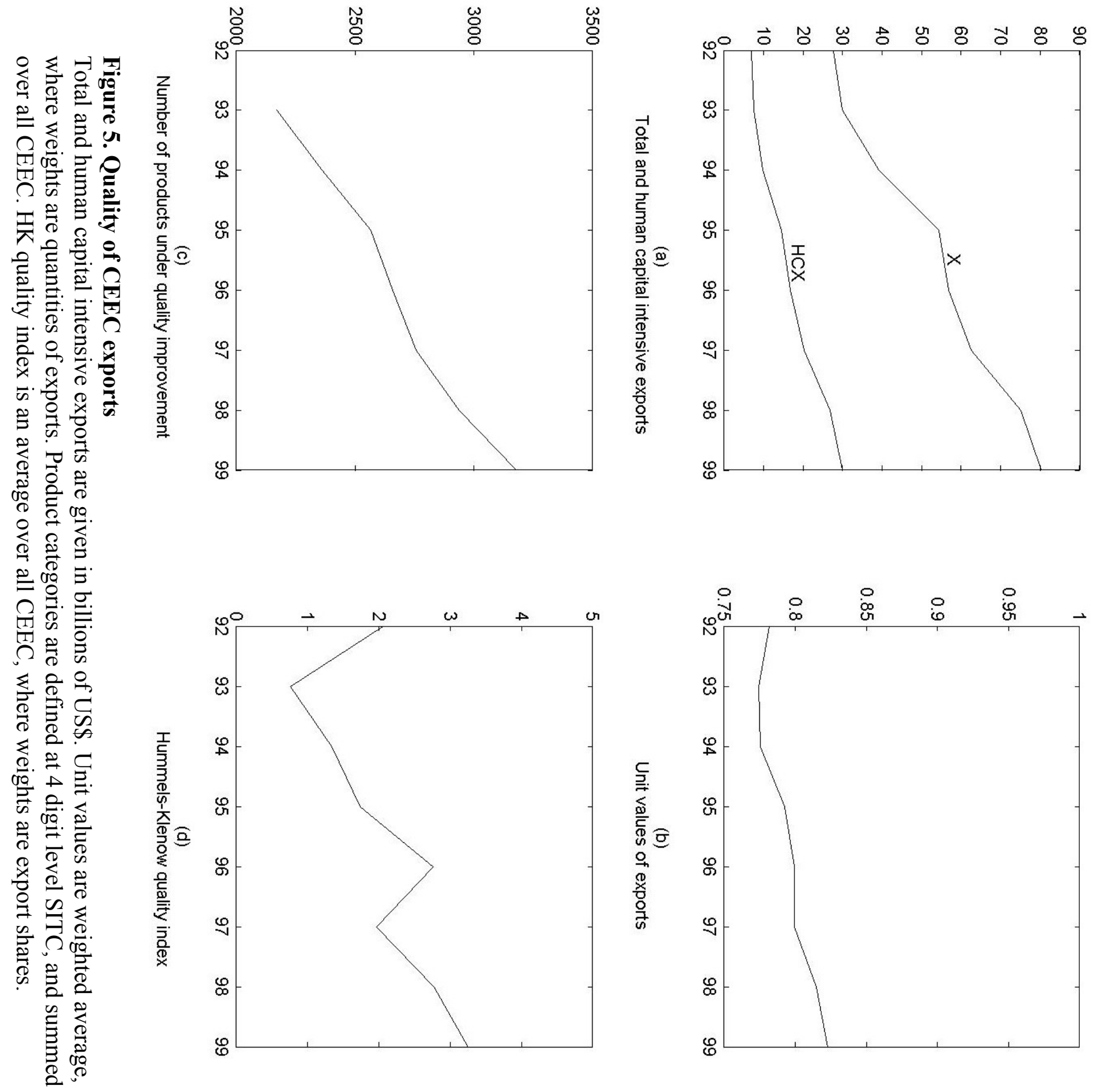




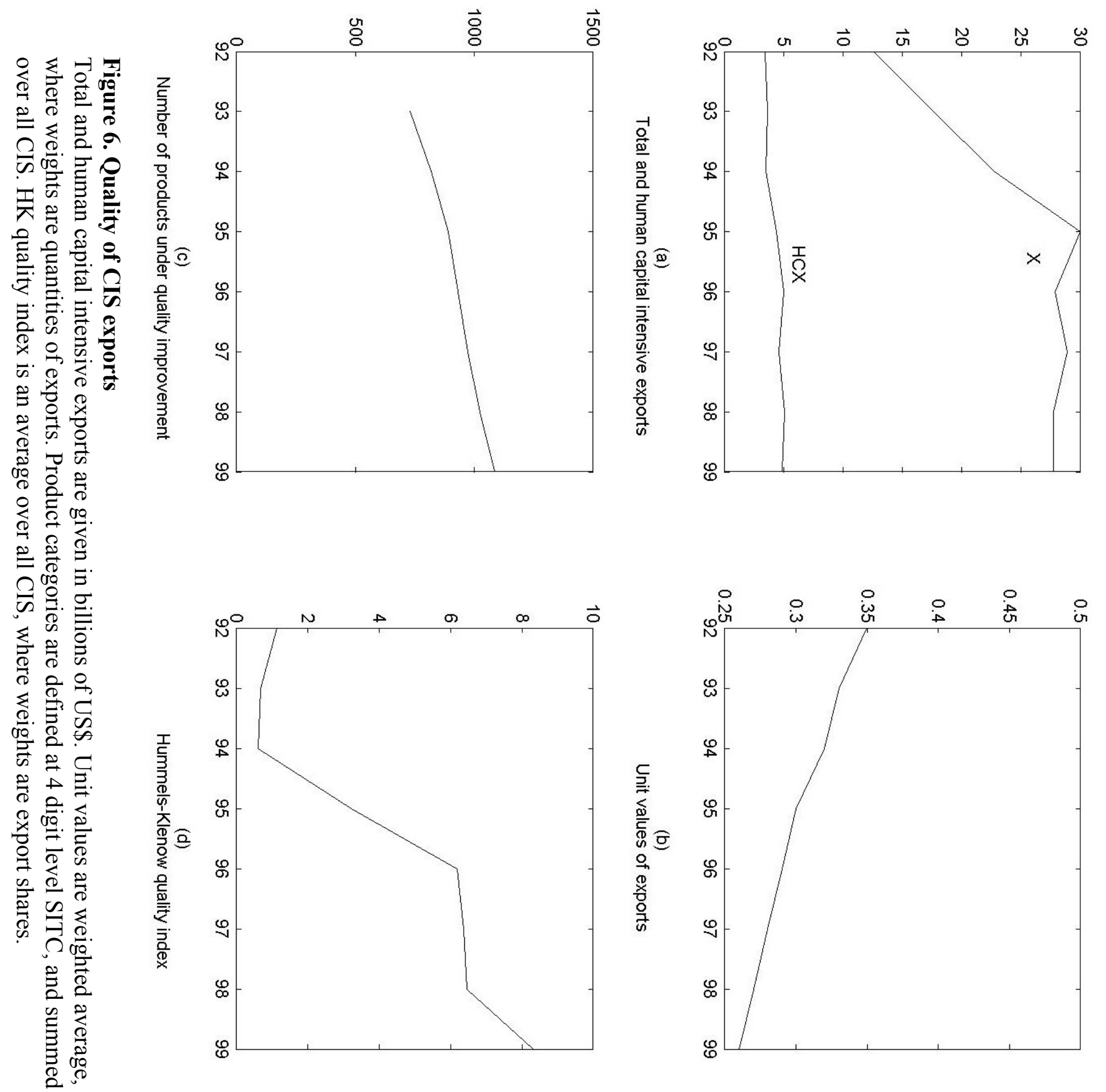




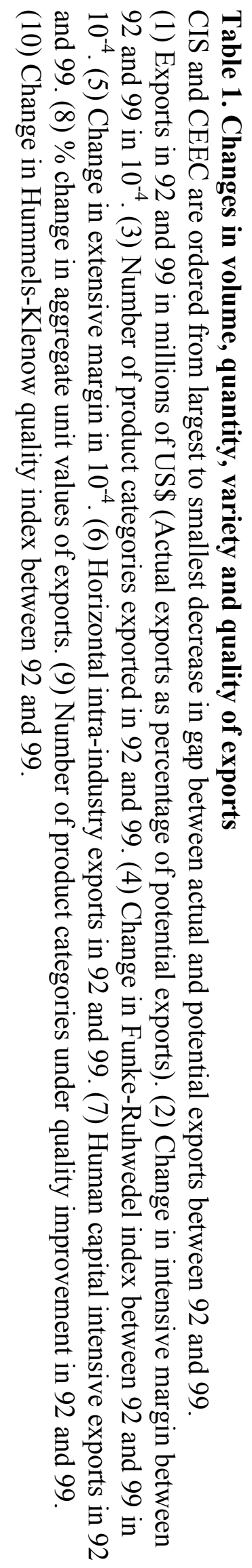

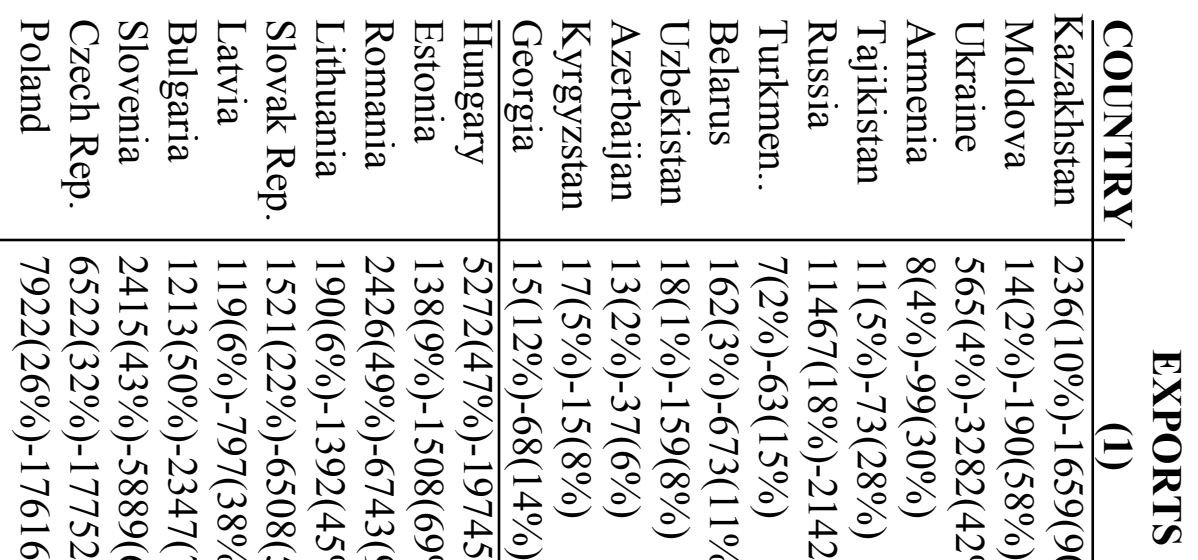

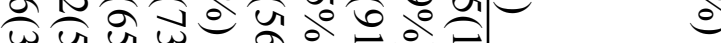

w vi w

a de é

อ อ

N N

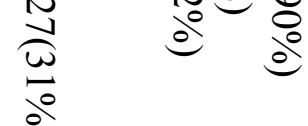

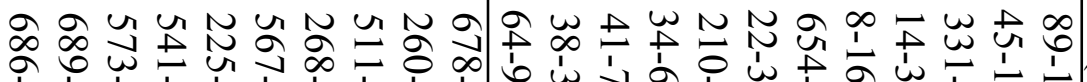

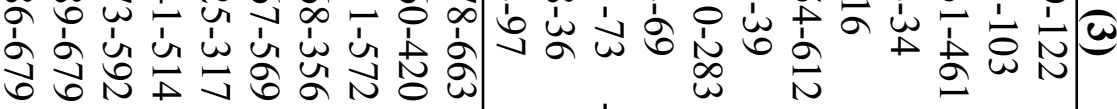

-

-

ఫે

চ

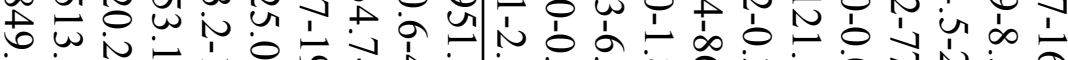

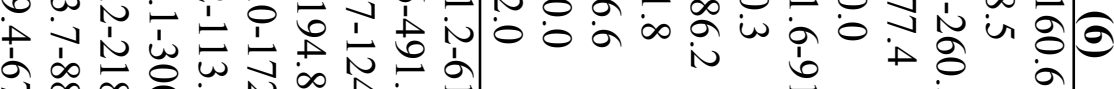

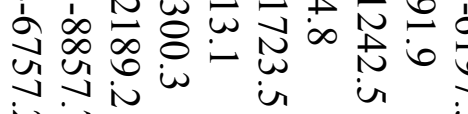

Әे

O

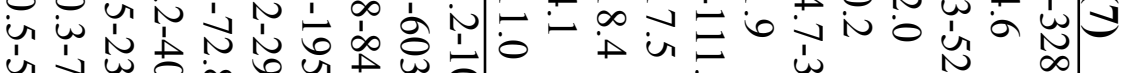

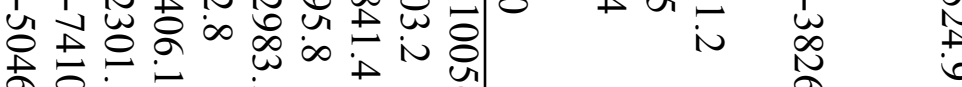

市宫:

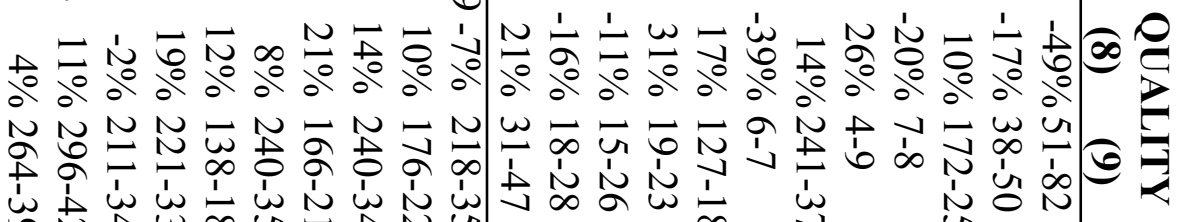

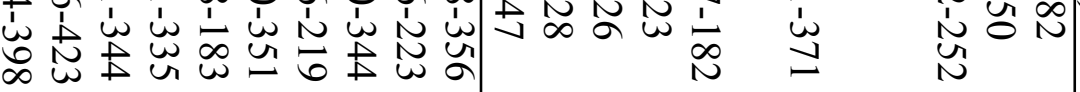

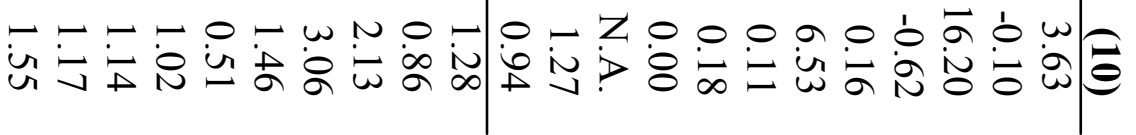


${ }^{1}$ These are Austria, Belgium, Brazil, Canada, China, Denmark, Egypt, Finland, France, Germany, Greece, Hong Kong, Indonesia, Italy, Japan, Korea, Luxembourg, the Netherlands, Norway, Portugal, Philippines, Singapore, Spain, Sweden, Switzerland, Thailand, Turkey, the UK, and the US.

${ }^{2}$ Interim Agreements on trade with the EU became effective by 1993 with Bulgaria, the Czech Republic, Estonia, Hungary, Latvia, Lithuania, Poland, Romania, and the Slovak Republic, and in 1996 with Slovenia. Russia, Kazakhstan, Belarus formed a customs union in 1994. Kyrgyzstan and Tajikistan joined in 1997, and 1999, respectively. Other CIS countries, Armenia, Azerbaijan, Georgia, Moldova, Turkmenistan, Ukraine, and Uzbekistan did not participate in this customs union.

${ }^{3}$ Product categories chosen are at 4-digit SITC. More disaggregated data was incomplete as the trade reported in 5-digit level or 6-digit level did not sum to overall trade volume.

${ }^{4}$ Because of the changes made to intensive margin formula, it no longer factors to a country's share in world exports with extensive margin.

${ }^{5}$ This result is in conjunction with Djankov and Hoekman (1996) that find limited redirection of traditional CMEA goods to OECD markets.

${ }^{6}$ Although the large volume of IIT is often cited as an element favoring Increasing Returns Trade Theory over H-O Theory, Davis (1995) provides an account of IIT within H-O framework with technical differences.

${ }^{7}$ Djankov and Hoekman (1996) also find high growth rates in vertical IIX of CEEC to EU in their early analysis, and reason it with high inflows of foreign direct investment.

${ }^{8}$ This justifies focusing on manufacturing sector in the analyses in the rest of the paper. 
${ }^{9}$ An earlier analysis by Landesmann and Burgstaller (1998) indicate that the quality gap between the EU, and Hungary, Poland, Slovenia and the Czech Republic narrowed during 1989-94, and the gap with Bulgaria and Romania widened.

${ }^{10}$ Grossman and Helpman (1991) provide such a model, where the south imitates the north, uses its lower wages to compete with the north. The north regains its advantage through innovation.

${ }^{11}$ Sheets and Boata (1998) too take the extent of reorientation of trade from CMEA to the EU as a sign of restructuring.

${ }^{12}$ This is consistent with the early analysis of Drabek and Smith (1995). Analyzing the period of 1989-94, they find that the unit values of EU imports from CEEC have fallen.

${ }^{13}$ The choice of another base country would only change the level, but the pattern of changes will be the same. 


\section{DAVIDSON INSTITUTE WORKING PAPER SERIES - Most Recent Papers}

The entire Working Paper Series may be downloaded free of charge at: www.wdi.bus.umich.edu

CURRENT AS OF $1 / 13 / 04$

\begin{tabular}{|c|c|c|}
\hline Publication & Authors & Date \\
\hline $\begin{array}{l}\text { No. 638: The Politics of Economic Reform in Thailand: Crisis and } \\
\text { Compromise }\end{array}$ & Allen Hicken & Jan. 2004 \\
\hline $\begin{array}{l}\text { No. 637: How Much Restructuring did the Transition Countries } \\
\text { Experience? Evidence from Quality of their Exports }\end{array}$ & Yener Kandogan & Jan. 2004 \\
\hline $\begin{array}{l}\text { No. 636: Estimating the Size and Growth of Unrecorded Economic } \\
\text { Activity in Transition Countries: A Re-Evaluation of Eclectric } \\
\text { Consumption Method Estimates and their Implications }\end{array}$ & Edgar L. Feige and Ivana Urban & Dec. 2003 \\
\hline No. 635: Measuring the Value Added by Money & Vlad Ivanenko & Nov. 2003 \\
\hline $\begin{array}{l}\text { No. 634: Sensitivity of the Exporting Economy on the External Shocks: } \\
\text { Evidence from Slovene Firms }\end{array}$ & $\begin{array}{l}\text { Janez Prašnikar, Velimir Bole, } \\
\text { Aleš Ahcan and Matjaž Koman }\end{array}$ & Nov. 2003 \\
\hline $\begin{array}{l}\text { No. 633: Reputation Flows: Contractual Disputes and the Channels for } \\
\text { Inter-firm Communication }\end{array}$ & William Pyle & Nov. 2003 \\
\hline $\begin{array}{l}\text { No. 632: The Politics of Development Policy and Development Policy } \\
\text { Reform in New Order Indonesia }\end{array}$ & Michael T. Rock & Nov. 2003 \\
\hline $\begin{array}{l}\text { No. 631: The Reorientation of Transition Countries' Exports: } \\
\text { Changes in Quantity, Quality and Variety }\end{array}$ & Yener Kandogan & Nov. 2003 \\
\hline $\begin{array}{l}\text { No. 630: Inequality of Outcomes and Inequality of Opportunities in } \\
\text { Brazil }\end{array}$ & $\begin{array}{l}\text { François Bourguignon, Francisco } \\
\text { H.G. Ferreira and Marta } \\
\text { Menéndez }\end{array}$ & Nov. 2003 \\
\hline No. 629: Job Search Behavior of Unemployed in Russia & Natalia Smirnova & Nov. 2003 \\
\hline $\begin{array}{l}\text { No. 628: How has Economic Restructuring Affected China's Urban } \\
\text { Workers? }\end{array}$ & John Giles, Albert Park, Feng Cai & Oct. 2003 \\
\hline No. 627: The Life Cycle of Government Ownership & Jiahua Che & Oct. 2003 \\
\hline $\begin{array}{l}\text { No. 626: Blocked Transition And Post-Socialist Transformation: Siberia } \\
\text { in the Nineties }\end{array}$ & Silvano Bolcic & Oct. 2003 \\
\hline $\begin{array}{l}\text { No. 625: Generalizing the Causal Effect of Fertility on Female Labor } \\
\text { Supply }\end{array}$ & $\begin{array}{l}\text { Guillermo Cruces and Sebastian } \\
\text { Galiani }\end{array}$ & Oct. 2003 \\
\hline $\begin{array}{l}\text { No. 624: The Allocation and Monitoring Role of Capital Markets: } \\
\text { Theory and International Evidence }\end{array}$ & Solomon Tadesse & Oct. 2003 \\
\hline No. 623: Firm-Specific Variation and Openness in Emerging Markets & $\begin{array}{l}\text { Kan Li, Randall Morck, Fan Yang } \\
\text { and Bernard Yeung }\end{array}$ & Oct. 2003 \\
\hline $\begin{array}{l}\text { No. 622: Exchange Rate Regimes and Volatility: Comparison of the } \\
\text { Snake and Visegrad }\end{array}$ & $\begin{array}{l}\text { Juraj Valachy and Evžen } \\
\text { Kočenda }\end{array}$ & Oct. 2003 \\
\hline $\begin{array}{l}\text { No. 621: Do Market Pressures Induce Economic Efficiency?: The Case } \\
\text { of Slovenian Manufacturing, 1994-2001 }\end{array}$ & $\begin{array}{l}\text { Peter F. Orazem and Milan } \\
\text { Vodopivec }\end{array}$ & Oct. 2003 \\
\hline $\begin{array}{l}\text { No. 620: Compensating Differentials in Emerging Labor and Housing } \\
\text { Markets: Estimates of Quality of Life in Russian Cities }\end{array}$ & $\begin{array}{l}\text { Mark C. Berger, Glenn C. } \\
\text { Blomquist and Klara Sabirianova } \\
\text { Peter }\end{array}$ & Oct. 2003 \\
\hline $\begin{array}{l}\text { No. 619: Are Foreign Banks Bad for Development Even If They Are } \\
\text { Efficient? Evidence from the Indian Banking Sector }\end{array}$ & $\begin{array}{l}\text { Sumon Bhaumik and Jenifer } \\
\text { Piesse }\end{array}$ & Oct. 2003 \\
\hline No. 618: The Echo of Job Displacement & $\begin{array}{l}\text { Marcus Eliason and Donald } \\
\text { Storrie }\end{array}$ & Oct. 2003 \\
\hline No. 617: Deposit Insurance During Accession EU Accession & $\begin{array}{l}\text { Nikolay Nenovsky and Kalina } \\
\text { Dimitrova }\end{array}$ & Oct. 2003 \\
\hline $\begin{array}{l}\text { No. 616: Skill-Biased Transition: The Role of Markets, Institutions, and } \\
\text { Technological Change }\end{array}$ & Klara Sabirianova Peter & Oct. 2003 \\
\hline $\begin{array}{l}\text { No. 615: Initial Conditions, Institutional Dynamics and Economic } \\
\text { Performance: Evidence from the American States }\end{array}$ & Daniel Berkowitz and Karen Clay & Sept. 2003 \\
\hline $\begin{array}{l}\text { No. 614: Labor Market Dynamics and Wage Losses of Displaced } \\
\text { Workers in France and the United States }\end{array}$ & Arnaud Lefranc & Sept. 2003 \\
\hline No. 613: Firm Size Distribution and EPL in Italy & $\begin{array}{l}\text { Fabiano Schivardi and Roberto } \\
\text { Torrini }\end{array}$ & Sept. 2003 \\
\hline
\end{tabular}

